\title{
FGF14 wt Allele
}

National Cancer Institute

\section{Source}

National Cancer Institute. FGF14 wt Allele. NCI Thesaurus. Code C147992.

Human FGF14 wild-type allele is located in the vicinity of $13 q 33.1$ and is approximately $692 \mathrm{~kb}$ in length. This allele, which encodes fibroblast growth factor 14 protein, plays a role in nervous system development. Mutation of the gene is associated with spinocerebellar ataxia 27. 